\title{
The Research on Cultivation Mode of Engineering Innovative Talents of "Internet plus Education"
}

\author{
Xiao-Dan ZHANG', Yan-Ming CHENG * and Yu-Xiang HAO
}

Beihua University, Jilin, China

Keywords: Internet plus; Engineering; Innovative talents; Cultivation

\section{Abstract.}

The cultivation of engineering innovative talents of "Internet plus education" is proposed with the development of economic globalization and multi-polarization of the world. It is a necessary demand for national development. The setting of cultivation target and type is the preliminary basis for cultivation of engineering innovative talents of "Internet plus education". It is to cultivate interest with the guidance of tutor; it is to cultivate team and pay attention to the practice; it is to design module and to invert courses and to start innovation mode. Network classroom is an effective way to cultivate engineering innovative talents of "Internet plus education “.

\section{The Significance of the Cultivation of Engineering Innovative Talents of "Internet plus Education"}

\subsection{The background of the cultivation of engineering innovative talents}

With the development of economic globalization and multi-polarization of the world the competition of science and technology is increasingly becoming an important factor in the competition between countries. In order to meet the need of development of talent competition and to keep China not to lag behind the world development trend it must enter the "Internet plus" era. In November 2014, Premier Li Keqiang attended the first session of World Internet Conference and pointed out that the Internet is a new popular tool for entrepreneurship and innovation. Internet is also called the "new engine" for upgrading the quality and efficiency of economy of China. It shows its important role. The cultivation of engineering talents is in accordance with national development needs and can combine with the mentioned concept of "Internet plus ".

\subsection{The inevitable requirement of cultivating engineering innovative talents}

Enterprise is the cell of national economy and its function for development of national economy is self-evident. If the core competitiveness of enterprises needs to be improved enterprises need innovation and need a lot of engineering innovative talents who must adapt to society and meet the social demand. In the "Internet plus" era it is inevitable to cultivate engineering talents who can adapt to the rules of the Internet. At present, there are a large number of engineering talents in China. But the quality of talents needs to be improved. The overall level of engineering technology is far away from developed countries. Our country has a large population and the employment problem can not be underestimated. If we want to alleviate the current employment problem we must actively cultivate engineering innovative talents.

\subsection{The realistic function of the cultivation of engineering innovative talents}

"Internet plus" has made the Internet as the core feature of the current development of information. It extracts the feature and completely integrates with industry, commerce and financial services. The period of transformation development of this economic society has put forward higher requirements for engineering innovative talents. Engineering innovative talents are conducive to meet the requirement. Cultivating talents with the mode of "Individualized quality education" is conducive for engineering talents to make correct understanding and position of themselves. So they can display their abilities. It is conducive to the long-term development of the universities and to promote the 
cooperation between universities and enterprises. It is helpful to cultivate high level talents welcomed by enterprises and to foster more competitive talents who will reach to the world and to enhance the comprehensive national power.

\section{The Content Of "Internet plus Education" of Engineering Innovative Talents}

\subsection{Cultivation objectives}

If there is no clear personalized cultivation objectives it is easy to form the phenomenon of talent convergence. "Internet plus education", which is a new form of education, can meet the trend of the times and match the high speed of information. It makes knowledge communication be convenient and efficient. It will also enable people to find a shortcut to knowledge and not to take the initiative to explore knowledge and to feel comfortable for the forefront idea of the Internet. Convenience brings efficiency but also it is a drawback which is easy to seek but is lack of innovation. The purpose of "Internet plus education" is to adapt to the development of the times in a better way and to supply better service for the academy and scholars. The purpose of convenience and efficiency is to facilitate better innovation and to develop their own ideas which can continue to absorb the frontier knowledge and to make better innovations and creation of new talents. In the Internet era, in addition to a number of disciplines storage, a strong sense of patriotism and social responsibility are the primary conditions. The structure of multiple abilities, good ideological and moral qualities and the spirit of social and humanistic care are the essential qualities of engineering innovative talents.

Team spirit, initiative and independence are to ensure the quality of engineering innovative talents. In the Internet era, it is essential to own the ability of sense of globalization, cross-cultural communication skills and information receiving and processing.

\subsection{Cultivation type}

The cultivation of engineering innovative talents starts from singular mode to diversification, multi type and multi-level. It is comprehensive development of "moral, intelligence, sports, aesthetics and labor" with "all flowers bloom together" and "not sticking to formalities". The cultivating talents should have good ideological and moral quality, the spirit of social and humanistic care and spirit of exploration. The specific categories are as following:

(1) Research oriented:

It is the academic type which can master the basic knowledge of the discipline and has a solid basic knowledge. With the analysis of problems and the ability to solve the problems the talents can put forward advanced theory and walk to the academic frontier with great endeavor and diligent thinking.

(2) Management type:

This type should have a strong professional knowledge and skill. It is more important for them to discover, to explore and to own innovative consciousness, idea, ability and creative character. It is necessary to equipped with an open and international perspective.

(3) Practice and creative type:

This type of talent must have a full range of knowledge storage and a wide range of books. And even psychology, aesthetic knowledge should be learned. Practice is the prerequisite for innovation. We not only learn from books but also make practice. Practice is equally important. As the name implies, practice of innovation refers to obtain a unique creative idea through the practice.

\section{Cultivation Approach of "Internet plus Education" of Engineering Innovative Talents}

\subsection{Guidance of tutor and cultivation of interest}

Creativity is an important part of the human body and a comprehensive quality. In the teaching process teachers should fully mobilize the active participation of students and stimulate students' initiative. Teachers must guide and cultivate the students in the teaching course with the advantage of the Internet and establish home and university alliance. So teachers can communicate with the 
students anytime and anywhere and share with students about engineering material and interesting stories. Teachers can introduce the history of Chinese and foreign engineering to students and encourage students to develop the habit of questioning. This can develop students' potential and creativity. Many children are not born to know what they are really interested in. The interest can only be found in contact with the acquired learning. Tutors should actively guide the students through the form of dialogue, discussion and communication.

\subsection{Cultivating team and focusing on practice}

According to the nature of the course, we can adopt the teaching mode of self-study with the assistance of group team. "Internet plus education" has a close relationship with the Internet. The Internet and the practice is not entirely antagonistic relationship. In the absorption of all kinds of theories network practice can also be carried out at the same time. It must not be empty talk. We should make the theory come from the Internet and apply it to practice. As the saying goes "Knowledge starts with practice" and "Everything must be only done then be understood profoundly". Internet and practice should complement each other. The Internet can be used to unite the various teams to achieve the sharing of resources. Problems can also be found and solved timely. And the research results can be quickly popularized to get improvement. This can mobilize the practical ability of each student. So that students are really involved in the discussion and get benefit and improvement.

\subsection{Design module and invert courses}

Expand students' right to choose courses. If we want to cultivate practical ability we need to increase the practice curriculum and integrate the innovation consciousness and ability, practical ability, English ability and comprehensive quality cultivation into the curriculum system. It is a good way to give students some autonomy on curriculum content and curriculum schedule. Compulsory courses and elective courses are set continuously and according to different type of students different credits are set for the cultivation of talents. Efficient use of resources is necessary. It is not limited to a fixed time and location and full release of innovative divergent thinking of students.

\subsection{Innovation mode and network classroom}

The brand-new educational mode brings brand-new educational method. The network is a new channel under the mode of Internet education where we can learn and absorb various excellent ideas. When you are unable to break through the bottleneck the words made by others will let you filled with wisdom. We can further improve the form of network teaching and to achieve and adapt to the era of networking. For example, the realization of global engineering curriculum resource sharing and MOOC is a good practice. It can be further promoted in all colleges and universities. This new mode can also be improved and it can be applied to cultivation of engineering innovative talents. Not only teachers can teach but also the experienced and talented engineers can also record the courses. In this way we can stimulate students' innovation ability and cultivate the engineering innovative talents to adapt to the trend of social development.

\section{Acknowledgements}

This work was supported by the Scientific and Technological Planning Project of Beihua University, China (No. YB201620).

\section{References}

[1] Zhang Wen. Based on the "Internet plus" cultivation mode of Higher Vocational Colleges [J]. Education Exploration, 2016, (12): 34-39. 
[2] Liu Youyao, Jiang Lin, Du Huimin, Zhang Liguo, Gong Jiamin, Liu Jihong. The Research and Practice on cultivation mode of Engineering Applicable innovative talents [J]. Research in Higher Education of Engineering, 2015, (05): 76-81.

[3] Su kezhi. The Research on Cultivation Mode of Innovative Engineering and Technical Talents of Research-based University[D]. Dalian University of Technology. 2013

[4] Di chengjie, Qiang min, Wang Zhaolong. The Research on the Cultivation Mode of Higher Education Innovation and Entrepreneurship talents Based on the "Internet plus" [J]. Journal of Chongqing University of Science and Technology (SOCIAL SCIENCE EDITION), 2016, (10): 109-112. 